\title{
腰椎沪り症例におけるMRI 像の検討
}

\author{
山口赤十字病院整形外科 \\ 佐々木 邦 雄・渡辺 浩一 \\ 松尾圭介・清 水敦 \\ 田丸卓 弥
}

\section{MR Imaging Assessment of Spondylolisthesis of the Lumbar Spine}

by

\author{
Kunio Sasaki, Koichi Watanabe, Keisuke Matsuo, \\ Atsushi Shimizu and Takuya Tamaru \\ Department of Orthopaedic Surgery, \\ Yamaguchi Red Cross Hospital
}

Twenty-nine patients with spondylolisthesis of the lumbar spine were evaluated by MR imaging, plain radiography and clinical sign. Disc hernia in olisthesis was classified into two types in $\mathrm{T} 1 \mathrm{w}$-images. Type 1 showed no herniated mass posterior to slipped vertebra. But in Type 2. disc material was displaced posterior to the vertebra.

Thirteen discs belonged to Type-1 and 19 discs to type-2. (in 4 patients, there existed olisthesis in two levels)

In type-2, fat tissue arround the root decreased in exit zone in eighty per cent cases. Clinical sign was more severe in patients with type-2 MR images.

MR imaging in spondylolisthesis seemed to be benefical for estimation of clinical sign. On planning of operative treatment, it is an essential examination for preventing complications.

\section{緒訔}

腰椎迄り症の病態に関与する因子としては, 过りの 程度・椎間板及び椎間関節の変性度・局所変形・不安 定性等の構築学的な異常とともに，それらに起因する 神経への圧迫病変・神経根の血行動態・䯣液の流れ等 が, 考えられる. 最近の各種検査の進歩により, 前述 の因子の解明が行われている. 今回我々は, 非侵襲性 であり従来の検査法に加え春椎管外の病変及び椎間板 の描出が可能な MRI にて，椎体前方之り症例にお ける椎間板の状態, 脊椎管外病変を検討し, 本疾患の 病態解明における MRI の有用性について言及する.

\section{方法}

MRI 像は SMT-100（超伝導・1.0 Tesla）を用い,
$\mathrm{SE}$ 法にて $\mathrm{T}_{1}$ 強調像（TR 500, $\left.\mathrm{TE} 34\right) \mathrm{T}_{2}$ 強調像 （TR 2000, TE 90）を求めた。 $\mathrm{T}_{1}$ 及び $\mathrm{T}_{2}$ 強調像と も原則として, 矢状断面像及び迄り部位での横断面像 を撮像した．MRI 像で検討した項目は，以下の如く である。

$\mathrm{T}_{1}$ 強調矢状面正中断面像に扔ける椎間板へルニア をType I : ヘルニアが汇り椎後下方に認められない もの, Type.II：ヘルニアが汇り椎後下方に認められ るものに分けた，又， $\mathrm{T}_{1}$ 強調像における神経周囲脂 肪組織よりの高信号領域の程度を正常・部分消失・完 全消失に分け，傍矢状断面像及び横断面像において評 価した，横断面像においては，立り椎下縁における春 椎管内病変を評価した。 T2 強調像においては, Gibson の分類 ${ }^{2)}$ に基づき, grade の評価を行った（図 $1)$. 


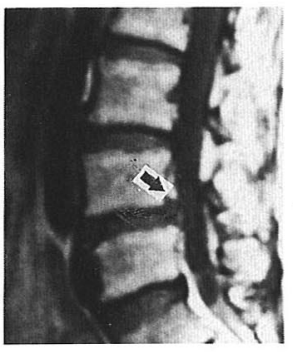

a

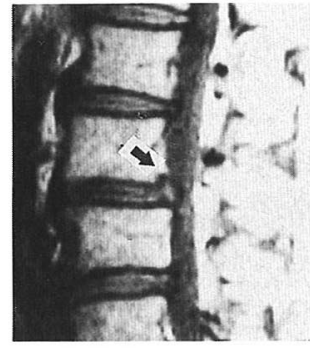

b
図 1 a $\mathrm{T}_{1}$ 強調像, 矢状面正中像

a. Type Iヘルニアは汇り椎後下方に存在 しない ( $\rightarrow$ 印)

b. TypeIIヘルニアは元り椎後下縁に存在 している（）印）

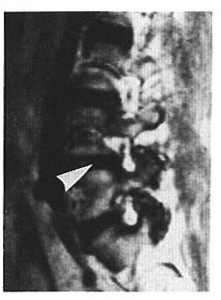

1

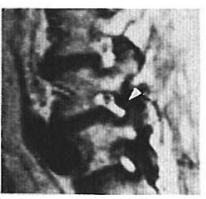

3 a

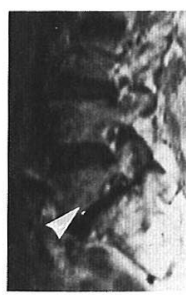

2

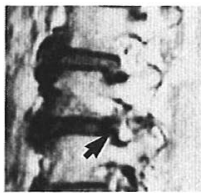

$3 \mathrm{~b}$
1 : 正 常

2 : 完全消失

3 : 部分消失

$\mathrm{a}$ : 背側のみ

$\mathrm{b}$ : 腹側のみ

c : 背側 ·腹側共

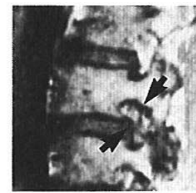

$3 c$
図 $1 \mathrm{~b} \mathrm{~T}_{1}$ 強調像, 傍矢状断面像

単純レ線像は，立体側面像を使用し Boxall 法 ${ }^{1)} に$ て汇り率を求めた。

臨床像は, 各症例における初診時の JOA スコアを 自・他覚所見にて求めた。

対

象

単純レ線像にて椎体の前方沪りが存在し MRI 像の 得られた 29 例を対象とした. 男性 6 例・女性 23 例で あった，平均年令は 61 才（41〜78）であった：过り のタイプは変性性 25 例, 分離过り症 5 例であり, 1 例は両方のタイプが存在していた，迄りのレベルは， 变性性 $\mathrm{L}_{3}: 5$ 椎体, $\mathrm{L}_{4}: 19$ 椎体, $\mathrm{L}_{5}: 4$ 椎体であ
り, 分離迄り症は, $\mathrm{L}_{4} ： 2$ 椎体. $\mathrm{L}_{5} ： 3$ 椎例であっ た. 2 椎体の云り存在例は 4 例であった.

\section{結果}

文り 1 椎間において, 椎間板が椎体内に迷入してお り，これを除外し残り 32 椎間の検討を行った.

a . 椎間板ヘルニア像の分布

前述の type I は 13 椎間 $\left(\mathrm{L}_{4 / 5}: 11, \mathrm{~L}_{5} / \mathrm{S}_{5}\right.$ :

2) であり, type II 19 椎間 $\left(\mathrm{L}_{3 / 4}: 4, \mathrm{~L}_{4 / 5}: 10\right.$, $\mathrm{L}_{5} / \mathrm{S}_{1}: 5$ ) であった.

b. 椎間板変性度とヘルニアのtype

椎間板変性度 grad 1，2 はなく，全例 grade 3或は 4 であった. type Iにおいては grade 3:7 椎間 (56\%) grade 4：6椎間（46\%）であり, type IIでは grade $3: 3$ 椎間 (16\%), grade 4: 16 椎 間（84\%）であった.

c . 过り率とへルニアの Type

type Iでは， L \& 迄り 11 椎体で汇り率の平均は 17 \% (15 23), $\mathrm{L}_{3}$ 立り 2 椎体で迄り率 12\%（11～15） であった. type II では， $\mathrm{L}_{4}$ 音り 4 椎体芒り率の平均 は 18\%（10２3），L５过り 5 椎体で迄り $27 \% （ 16 〜$ 40）であった. type I 全体での芒り率は平均 $16 \%$ (11〜23)，typeIIにおいては 19\%（10４0）であっ た.

\section{d. T, 強調像傍矢状断面像 (表 I a )}

この MRI 像は解剖学的に云えば, 椎間孔出口部 （いわゆる exit zone）を示すと考えれる. 検討を行っ

表 1 a Exit Zoneの所見

\begin{tabular}{|c|c|c|c|c|}
\hline & & & Type 1 & Type 2 \\
\hline 正 & & 常 & 6 & 1 \\
\hline 部 & 分 消 & 失 & 13 & 21 \\
\hline 完 & 全 消 & 失 & 0 & 9 \\
\hline 判 & 断 不 & 能 & 7 & 7 \\
\hline \multicolumn{3}{|c|}{ 計 } & 26 根 & 38 根 \\
\hline
\end{tabular}

表 1 b Dorsal Root Ganglion の所見

\begin{tabular}{|c|c|c|c|c|}
\hline & & & Type 1 & Type 2 \\
\hline 正 & & 常 & 19 & 11 \\
\hline & 分 消 & 失 & 5 & 18 \\
\hline 完 & 全 消 & 失 & 0 & 6 \\
\hline 判 & 断 不 & 能 & 2 & 3 \\
\hline \multicolumn{3}{|c|}{ 計 } & 26 根 & 36 根 \\
\hline
\end{tabular}


た神経根は type I : 26 根 type II：38 根であった. このうち判定不能（頭尾側の椎開においても撮像不良 のもの）は, 両者共 7 根であった. type I は正常像 が 6 根にみられ完全消失はなく，逆に type Iにおい ては 9 根が完全消失で正常像は 1 根のみであった。部 分消失は type I：13 根, type II：21 根であった.

e. $\mathrm{T}_{1}$ 強調像横断面像 (表 I b )

过り椎下縁の横断面像においては脊髄神経節（以下 DRG と略す）が描出されるが，この像においては DRGの像について検討を行った. type I : 2 根 type II：3根が判定不能であった. type Iにおいて は19 根が正常像を示し完全消失は存在しなかった. type IIにおいては完全消失は 6 根であり正常像は 11 根であった. 部分消失は, type I : 5 根, type II : 18 根であった.

迄り下位椎上縁の横断面像においては, 脊椎外側陥 凹部を主とするいわゆる entrance zone を描出する. 判定不能は type Iの 2 根のみであった. type Iにお いては, 正常 2 根・部分消失 1 根・完全消失 21 根で あった. type II では, 正常 2 根・部分消失 11 根・完 全消失 25 根であった.

$\mathrm{f}$. 臨床所見と MRI 像（特にヘルニア像）との比較 JOA スコアの自・他覚所見の点数の和で臨床症状 を評価した，他部位病変合併の為判定不能とした例が， type I：2, type II：2例であり残り 25 例にて比較 した.

type I （ 8 例）の平均は 10 点 $(4 \sim 13)$ でtype II (17 例) の平均は 7 点 $(1 \sim 11)$ であった.

選択された治療法は type I 8 例は全例保存的治療で り, type II 17 例中 6 例に手術的治療が施行された.

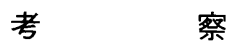

沪り症の症状発現には複数の因子が関与し, 個々の 症例における病態解明には慎重な検討を要する。従来 我々は, 臨床症状及び経過の検討及び各種レ線学的検 査法にて, 病態把握を行い治療法の選択を行ってきた. MRI 像はそれらのレ線的検查法に加え, 更なる病的 変化を示してくれる，我々が今回検討した所見は，空 間分解能のよい T 1 強調像にて椎間板ヘルニアの形態 及び脊椎管内外での神経組織への圧迫病変である. 又, $\mathrm{T}_{2}$ 強調像にては, 本症の重要な病変と考えられる椎 間板変性度を示してくれる，神経周囲脂肪組織よりの
信号は神経周囲の状態を反映すると考えられるが, 大 多数の例において判定可能であった。しかし，过りに 伴う脊柱変形存在例においては撮像が悪く, 判定不能 となることがあるので留意する必要がある.

云り率と椎間板変性度の間に有意の相関はみられな かったも, 全例 grade $3 ， 4$ 例であり椎間板変性は 立り例においては高度であることを示している，椎間 板ヘルニア像と変性度の関係をみると, type IIに明 らかに変性高度であることが判明した。妄り症例にお いては，椎間板変性の進行に伴い変性椎間板はより広 範囲な神経圧迫要因となることを，示していると考え られた。

立り症例における神経圧迫病変は, 春椎管内のみで なく脊椎管外にも存在する．従来のレ線学的評価法に おける春椎管外病変の把握は, 神経根造影・椎間板造 影或は $\mathrm{CT}$ 像にて把握されていた。しかし，前 2 者は 描出部位が限定されかつ侵襲的であり，又， CT 像は 判定困難と考えられる面を有していた，MRIはこれ らの短所を克服し，非侵襲的に情報を与えてくれるこ とより ${ }^{5)}$ ，有用と考えられる．MRI 像の検討より， 沪り症における准管外病変は, type II の椎間板へ ルニア像を有する例に高頻度に認められた。我々は, $\mathrm{DRG}$ への圧迫・牽引病変が下肢症状発現に重要な役 割を有する可能性を以前指摘した ${ }^{3 \text { (4)6) }}$. type II に高 頻度にみられた脊椎管外病変部位には DRG が存在 しており，吂り症例においてはDRGの病態の関与 を考慮する必要性を示している. 今回詳細な検討を行っ ていないが, 症例の臨床所見・治療法の選択よりみて type II がより高度な症状を発現していると考えられ， この面よりの検討は治療法選択の一助となると思われ る. 実際の DRG 病変把握の際は, 個々の症例にお けるDRGの泰椎に占める位置に注意する必要があ る. 又, type II におけるこの様な脊椎管外病変の高 頻度な存在は, 过り症例に対する整復操作時に外側ま で充分除圧を行う必要生を示していると考えられた.

\section{結語}

(1)腰椎沪り症 29 例において，単純レ線（过り率） MRI 像・臨床所見の比較検討を行った.

(2) MRI 像（ $\mathrm{T}_{1}$ 強調矢状面正中断像）において椎 間板ヘルニア像を, 椎体下縁へのヘルニアの存在の有 無により Type I とIIに分けた. 
(3)之り率と Type の間には関連が認められなかった. (4)椎間板变性度が高度の例に Type II にが多かった.

(5) Type II においては, 脊椎管外病変の存在例が多 かった.

(6) Type II における臨床症状は高度で手術的治療を 必要とする症例が多かった。

\section{文献}

1) Boxzll D. et al.: Mangement of severe spondylolisthesis in children and adolescents. J Bone Joint Surg
61 A : 479-495, 1979.

2) Gibson MJ. et al.: Magnetic resonance imaging and discography in the diagnosis of disc degeneration. J Bore Joint Surg 68-B : 369-373, 1986.

3）佐々木邦雄他：腰椎骨棘の臨床的意義, 椎間孔外での 神経圧迫における. 整外と災外, 38：111-114, 1989.

4）佐々木邦雄他：腰椎疾患における春髄神経節の臨床的 意義. 日整会誌, $63:$ S 50, 1989.

5）清水 敦他: 腰椎管外神経根障害の判断と治療. 整外 と災外, $39: 501-504,1990$.

6）田丸卓弥他: 脊髄神経節圧迫障害について, 整外と災 害, $37: 1135-1138,1989$. 